\title{
PERANCANGAN APLIKASI PEMINDAI HARGA DAN REKOMENDASI PRODUK MENGGUNAKAN METODE TOPSIS BERBASIS ANDROID
}

\author{
Eko Teguh Wicaksono $^{1}$, Haris Yuana ${ }^{2}$, M. Taofik Chulkamdi ${ }^{3}$ \\ 1,2,3 Teknik Informatika S1 Universitas Islam Balitar Blitar \\ ekoteguhwicaksono@gmail.com
}

\begin{abstract}
ABSTRAK
Toko swalayan Sea Mart merupakan salah satu minimarket yang bergerak dalam usaha perdagangan ritel offline. Pada toko ini tidak diberikan label harga pada barang yang dijual namun sebagai gantinya mereka menyediakan mesin pemindai harga barang meskipun dalam jumlah terbatas. Oleh karena itu dibutuhkan suatu alternatif untuk memudahkan pembeli dalam mengetahui harga barang namun tidak menyulitkan pemilik usaha ataupun karyawan dalam mengubah harga dari barang-barang yang jumlahnya sangat banyak tersebut. Untuk mengatasi hal itu aplikasi pemindai harga barang dan rekomendasi produk berbasis android menawarkan solusi untuk menyelesaikan permasalahan ini. Penelitian ini dilakukan dengan menggunakan metode Research \& Development dan didukung dengan metode pengembangan perangkat lunak Prototyping. Pengujian aplikasi pemindai harga barang berbasis android ini dilakukan menggunakan metode black box pada perangkat android Realme U1 yang menjalankan android versi 9/ pie dan mendapatkan hasil 88,89\% sesuai dengan harapan. Hasil pengujian mendapatkan nilai tersebut dipengaruhi oleh berbagai faktor seperti: kompatibilitas pustaka pemindai dengan perangkat pengguna, versi android pengguna, dan juga perangkat keras pengguna.
\end{abstract}

Keyword : Penjualan, Pemindai, Ritel, Black Box, TOPSIS

\section{PENDAHULUAN}

Sektor perdagangan saat ini merupakan bisnis yang berkembang sangat pesat. Ditambah lagi dengan internet dan teknologi pendukung lainnya yang juga berkembang sangat cepat menjadikan persaingan di bidang ini berlangsung sangat ketat dan seakan saling menggusur satu sama lain. Oleh karena itu inovasi-inovasi baru selalu dibutuhkan oleh pelaku usaha sehingga tidak tertinggal kemudian tergerus oleh kemajuan teknologi.

Sektor eceran dalam pembangunan nasional memegang peranan yang cukup penting, bukan saja ujung tombak dari pemasaran produksi nasional, tetapi juga merupakan pemasukan pendapatan negara yang tidak sedikit dan menyerap tenaga kerja yang cukup besar. Sektor perdagangan eceran perlu terus dikembangkan dalam upaya penyerapan tenaga kerja dan pemasukan sektor pendapatan. Perdagangan yang dikembangkan tersebut tidak hanya menyangkut pedagang eceran tradisional tetapi juga pedagang modern seperti pasar swalayan (Ohy, 2010).

Penelitian ini mengambil studi kasus pada toko swalayan Sea Mart yang terletak di jl. TGP no. 7-911 kota Blitar. Toko ini tidak memberikan label harga pada produk-produk yang mereka jual namun memberikan alternatif dengan menyediakan beberapa mesin pemindai harga sehingga jika ada pembeli ingin mengetahui harga suatu barang maka mereka harus membawa barang tersebut ke pemindai harga yang telah disediakan kemudian memindai barcode dari barang tersebut dan informasi mengenai harga barang itu akan ditampilkan kepada calon pembeli. Berdasarkan wawancara yang telah dilakukan kepada beberapa pembeli dan juga karyawan, metode ini memberikan beberapa masalah yaitu ketidaknyamanan pembeli jika harus membawa barang yang akan dibeli ke mesin pemindai kemudian mengembalikan ke tempat semula jika tidak jadi membeli, apalagi jika harus mengantri hanya untuk mengecek harga sebuah barang. Selain itu metode ini berisiko untuk mengacaukan letak barang-barang yang ada pada toko tersebut dikarenakan pembeli yang mengembalikan barang tidak secara benar. Di sisi lain jika toko swalayan harus menyediakan banyak pemindai, maka akan membutuhkan biaya investasi dan operasional yang besar.

Dengan adanya beberapa permasalahan tersebut penulis menilai dibutuhkan adanya sebuah rancangan sistem yang memungkinkan toko swalayan mengubah harga barangnya secara efektif dan efisien, dengan modal investasi dan biaya operasional yang kecil serta meniadakan risiko ketidaksesuaian antara harga barang dan harga sebenarnya dengan cara menyediakan suatu aplikasi berbasis android yang mampu melakukan pemindaian harga barang-barang yang ada di toko swalayan. Dengan menggunakan aplikasi ini calon pembeli bisa mengetahui harga barang dengan smartphone milik mereka sendiri, pemilik toko pun tidak perlu khawatir dengan investasi awal serta biaya operasional yang mahal seperti jika menggunakan banyak mesin pemindai, selain itu pemilik toko tidak perlu khawatir rak barangnya acak-acakan karena calon pembeli yang mengembalikan barang tidak pada tempatnya setelah melakukan pengecekan harga. Selain itu untuk meningkatkan potensi penjualan maka ditambahkan sistem rekomendasi produk sejenis menggunakan metode TOPSIS. 


\section{TINJAUAN PUSTAKA}

2.1. Metode TOPSIS (Technique for Order of Preference by Similarity to Ideal Solution)

TOPSIS adalah salah satu metode pengambilan keputusan multikriteria (MCDS) yang pertama kali diperkenalkan oleh Hwang dan Yoon pada tahun 1981. Dengan ide dasarnya adalah bahwa alternatif yang dipilih memiliki jarak terdekat dengan solusi ideal positif dan yang terjauh dari solusi ideal negatif.

TOPSIS memperhatikan baik jarak ke solusi ideal positif maupun jarak ke solusi ideal negatif dengan mengambil hubungan kedekatan menuju solusi ideal. Dengan melakukan perbandingan pada keduanya, urutan pilihan dapat ditentukan.

Metode TOPSIS banyak digunakan pada beberapa model MADM (Multi Attribute Decision Making) dikarenakan metode ini memiliki beberapa keunggulan (Yoon dan Hwang,1981), yaitu:

a. Konsepnya sederhana dan mudah dipahami

b. Komputasinya efisien.

c. Memiliki kemampuan untuk mengukur kinerja relatif dari alternatif-alternatif keputusan dalam bentuk matematis yang sederhana.

\subsection{Kajian Penelitian}

Beberapa penelitian sebelumnya yang digunakan sebagai referensi terhadap penelitian yang dilakukan saat ini antara lain:

Febiyanti pada tahun 2018 melakukan penelitian tentang Implementasi Barcode Scanner Pada Aplikasi Cek Harga dan Hitung (SI-CEKING) Berbasis Mobile. Dengan aplikasi tersebut konsumen swalayan atau tempat berbelanja telah dapat dengan mudah melakukan hitung total harga barang belanjaan tanpa harus memperkirakan ataupun menghitung jumlah total harga barang belanjaan menggunakan kalkulator maupun alat hitung manual lainnya (Febiyanti, 2018).

Putra Yudha dkk pada 2017 melakukan penelitian tentang perancangan aplikasi sistem inventory barang menggunakan barcode scanner berbasis android. Aplikasi ini dapat melakukan pencarian data stok barang di seluruh outlet Krisna Oleh-Oleh Bali karena memiliki database yang dapat diakses oleh semua user yang sudah diregistrasi oleh Admin. Aplikasi ini juga dapat digunakan pada smartphone Android, sehingga dalam pemakaiannya dapat mempermudah user dalam melakukan pengecekan stok barang tanpa harus melalui Operator toko ataupun mengecek secara manual (Putra Yudha, Sudarma, \& Arya Mertasana 2018).

SuryawaVn, Hasiri, \& Ode pada 2020 melakukan penelitian berjudul "Penerapan Sistem $Q R$ Code dan Barcode dalam Menghitung Belanja di Swalayan Berbasis Android". Dengan adanya aplikasi menghitung belanja di swalayan menggunakan $Q R$ code dan barcode reader berbasis android dapat memudahkan pelanggan dalam membeli barang dan melakukan transaksi pembayaran. Pelanggan menggunakan aplikasi android untuk membeli barang dengan bantuan kamera handphone untuk scanning $Q R$ code dan barcode untuk menampilkan harga barang dan total belanja.
Pembayaran barang dilakukan dengan scanning $Q R$ Code di meja kasir dan akan divalidasi oleh kasir untuk melakukan pembayaran belanja tunai.

Ardana dkk pada 2019 melakukan penelitian yang bertujuan untuk membuat sistem penagihan otomatis yang diterapkan pada aplikasi berbasis smartphone android dengan login akun untuk transaksi cashless. Login akun ini digunakan untuk proses pemindaian $Q R$ Code menggunakan smartphone android yang terdapat pada aplikasi guna menampilkan informasi yang terdapat pada produk. Aplikasi ini juga terdapat fitur menyimpan uang elektronik yang digunakan untuk membayar setelah proses pemindaian serta verivikasi kode unik untuk pembayaran.

Penelitian sebelumnya yang memiliki banyak kesamaan dengan penelitian ini adalah penelitian yang dilakukan oleh Febiyanti pada 2018 yaitu penelitian tentang Implementasi Barcode Scanner Pada Aplikasi Cek Harga dan Hitung (SI-CEKING) Berbasis Mobile. Diantara 2 penelitian ini terdapat beberapa kesamaan yaitu penggunaan android sebagai basis aplikasi dan penggunaan barcode sebagai fokus utama aplikasi. Namun penelitian yang yang diajukan pada proposal ini memiliki beberapa kelebihan dibanding penelitian yang dilakukan oleh Febiyanti yaitu pengguna tidak perlu melakukan registrasi dan juga bisa digunakan di lebih dari satu toko.

\section{METODE PENELITIAN}

Berikut ini adalah teknik pengumpulan data dan implementasi yang digunakan dalam penelitian ini.

\subsection{Teknik Pengumpulan Data}

Teknik pengumpulan data yang dilakukan oleh peneliti pada penelitian ini dilakukan dengan cara melakukan observasi bertempat di swalayan Sea Mart yang beralamat di jl. TGP no. 7-9-11 Kel. Kepanjenkidul, Kec. Kepanjen Kidul, Kota Blitar serta memberikan kuisioner kepada pengunjungpengunjung Sea Mart.

\subsection{Membangun Prototype}

Membangun prototype dengan membuat perancangan sementara yang berfokus pada penyajian kepada pengguna dengan desain flowchart sistem, diagram context, data flow diagram, entity relationship diagram, struktur basis data dan desain layout antar muka pengguna. Tahapan membangun prototype pada penelitian ini adalah sebagai berikut:

\subsection{Flowchart Sistem}

Berdasarkan analisa terhadap hasil observasi dan juga kuisioner, disimpulkan bahwa dibutuhkan adanya suatu sistem pemindai harga barang dan rekomendasi produk berbasis android untuk memudahkan pengguna ketika berbelanja. Berikut adalah flowchart sistem yang digunakan dalam sistem ditampilkan pada gambar 1 


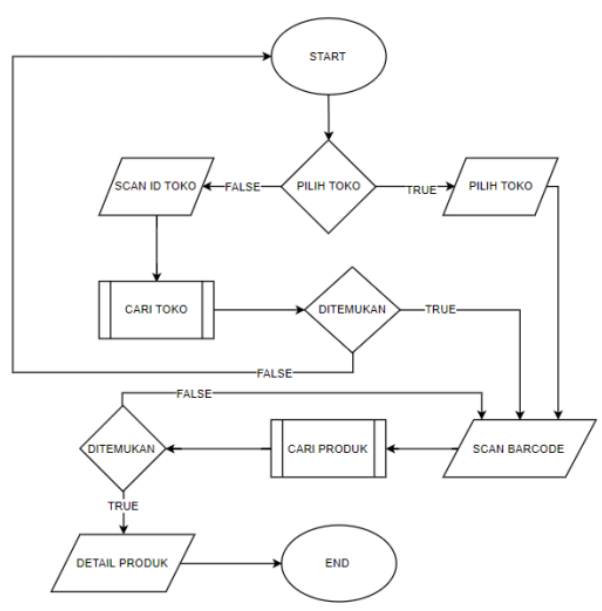

Gambar 1. Flowchart sistem

\subsection{Diagram Context}

Untuk menggambarkan bagaimana hubungan entitas luar, masukan serta keluaran sistem maka digunakan diagram context. Adapun diagram konteks dari aplikasi pemindai harga barang berbasis android yang akan dirancang dapat dilihat pada gambar 2

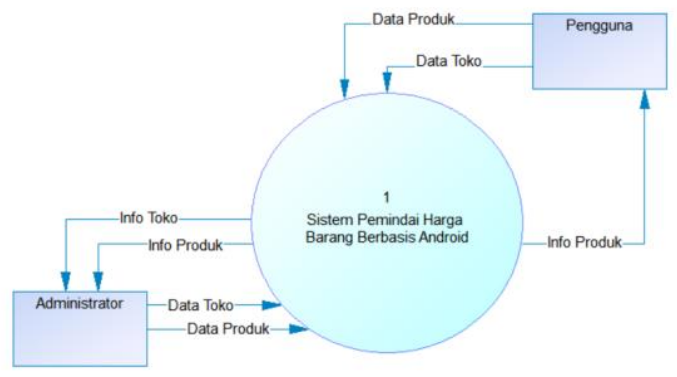

Gambar 2. Diagram Context

\subsection{Data Flow Diagram}

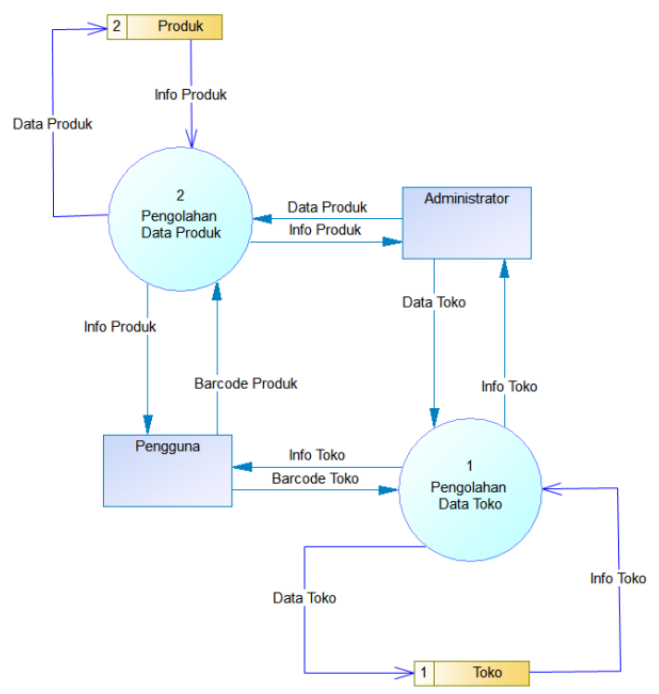

Gambar 3. Data Flow Diagram
Menjelaskan proses yang ada di dalam sistem yang di bangun berdasarkan diagram konteks, adapun proses tersebut di bagi menjadi 2 (dua), yaitu pengolahan data toko dan pengolahan data produk. DFD level 1 dari aplikasi pemindai harga barang berbasis android yang akan dirancang dapat dilihat pada gambar 3

\subsection{Pemodelan Data}

ERD atau Entity Relational Diagram adalah alat pemodelan data utama dan akan membantu mengorganisasi data dalam suatu proyek ke dalam entitas-entitas dan menentukan hubungan antar entitas.

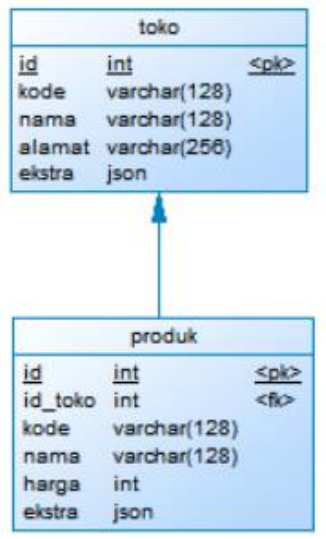

Gambar 4. Entity Relational Diagram

\subsection{Evaluasi Prototype}

Proses evaluasi ini dilakukan pengguna untuk mengetahui apakah prototype yang telah dibangun sudah sesuai dengan kebutuhan pengguna. Jika sudah sesuai maka diambil langkah keempat. Jika tidak, maka prototype diperbaiki dengan mengulang tahap 1, 2, dan 3. Tahap ini peneliti melakukan evaluasi prototype pada kegiatan seminar proposal, dan hasil dari evaluasi prototype tidak ditemukan kekurangan kebutuhan sistem pada tahap prototype, maka dari hasil tersebut peneliti melakukan tahap selanjutnya yaitu pengkodean sistem.

\subsection{Pengkodean Sistem}

Dalam tahap ini prototype yang sudah disetujui dilakukan pembuatan sistem. Tahapan-tahapan pengkodean sistem adalah sebagai berikut :

\section{Tahap pembuatan daftar toko terakhir}

Tahap pembuatan daftar toko terakhir adalah tahap yang pertama kali dikerjakan dikarenakan untuk masuk ke halaman pemindai harga bisa menggunakan cara melakukan tap pada daftar toko terakhir ataupun dengan melakukan pemindaian barcode toko terlebih dahulu. Daftar toko terakhir didapatkan dengan cara mengirimkan id toko yang tercatat di perangkat android ke server kemudian hasilnya ditampilkan kepada pengguna. 


\section{Tahap pembuatan sistem pemindai}

Selanjutnya adalah pembuatan sistem pemindai yang merupakan fitur dasar aplikasi ini yang akan digunakan pada halaman pemindai toko dan pemindai harga. Pada tahap ini peneliti mencoba beberapa pustaka yang bisa digunakan dengan fleksibel dan mudah digunakan hingga akhirnya menemukan library pemindai qr code dan barcode yang dibuat oleh Yuriv Budiyev.

\section{Tahap TOPSIS}

Selanjutnya setelah membuat sistem pemindai, maka proses terakhir adalah membuat sistem rekomendasi produk menggunakan metode TOPSIS. Untuk membuat sistem rekomendasi ini peneliti membuat simulasi perhitungan TOPSIS pada spreadsheet excel yang nantinya hasilnya akan dijadikan patokan untuk menentukan kebenaran hasil dari keluaran sistem yang nantinya dibuat.

\section{HASIL DAN PEMBAHASAN}

\subsection{Paparan Data}

Setelah peneliti melakukan penelitian di toko swalayan Sea Mart, kota Blitar dengan metode observasi dan pemberian kuisioner dapat dipaparkan hasil penelitian sebagai berikut. Penelitian ini dilakukan untuk mengetahui apa saja yang diperlukan untuk merancang sistem pemindai harga barang dan rekomendasi produk menggunakan metode TOPSIS, yaitu sebagai berikut.

\subsection{Hasil Kuisioner}

Peneliti memberikan kuisioner kepada beberapa orang pengunjung Sea Mart dan didapatkan 50 orang responden. Untuk mendapatkan umpan balik dari para responden atas kebijakan Sea Mart yang tidak memberi label harga pada item dagangannya dan juga serta rencana peneliti untuk menyediakan aplikasi pemindai harga maka peneliti melakukan penggalian data dengan memberikan beberapa pertanyaan dan menghasilkan data sebagai berikut.

Tabel 1. Sebaran Data Umur Responden

\begin{tabular}{|c|l|c|}
\hline No & \multicolumn{1}{|c|}{ Umur } & Jumlah \\
\hline 1 & Kurang dari 23 & 22 \\
\hline 2 & 24 hingga 30 & 12 \\
\hline 3 & 31 hingga 40 & 13 \\
\hline 4 & Lebih dari 40 & 3 \\
\hline
\end{tabular}

Tabel 2. Sebaran Data Profesi Responden

\begin{tabular}{|c|l|c|}
\hline No & Pekerjaan & Jumlah \\
\hline 1 & Guru & 8 \\
\hline 2 & IRT & 4 \\
\hline 3 & Karyawan Swasta & 2 \\
\hline 4 & Mahasiswa & 16 \\
\hline 5 & Wiraswasta & 15 \\
\hline 6 & PNS & 3 \\
\hline 7 & Lainnya & 2 \\
\hline
\end{tabular}

Tabel 3. Pilihan Responden untuk Solusi Penghilangan Label Harga

\begin{tabular}{|c|l|c|}
\hline No & \multicolumn{1}{|c|}{ Pilihan } & Jumlah \\
\hline 1 & Aplikasi & 14 \\
\hline 2 & Mesin Pemindai & 30 \\
\hline 3 & Bertanya kepada karyawan & 4 \\
\hline 4 & Lainnya & 2 \\
\hline
\end{tabular}

Tabel 4. Kenyamanan Responden Terhadap Mesin Pemindai Harga

\begin{tabular}{|c|l|c|}
\hline No & \multicolumn{1}{|c|}{ Pilihan } & Jumlah \\
\hline 1 & Nyaman & 34 \\
\hline 2 & Tidak Nyaman & 16 \\
\hline
\end{tabular}

Tabel 5. Alasan Responden Merasa Nyaman dengan Penggunaan Mesin Pemindai

\begin{tabular}{|c|c|}
\hline No & Alasan \\
\hline 1 & $\begin{array}{l}\text { Nyaman aja klo kebiasaan. tp masalah } \\
\text { kemudahan, klo bisa lewat hp aja kenapa harus } \\
\text { ribet lewat komputer }\end{array}$ \\
\hline 2 & Ada kesenangan tersendiri \\
\hline 3 & $\begin{array}{l}\text { Nominal harganya sdh pasti tanpa harus } \\
\text { bertanya-tanya }\end{array}$ \\
\hline 4 & Gampang lihat harga \\
\hline 5 & meminimalisir impulsif buying \\
\hline 6 & Ruangan nya luas \\
\hline 7 & Efisien praktis \\
\hline 8 & $\begin{array}{l}\text { Karena kita bisa mengetahui harga dengan tepat, } \\
\text { tidak seperti yang sering terjadi di swalayan lain } \\
\text { contohnya alf* atau ind*mar*t harga yang } \\
\text { tercantum (biasanya) tidak sama dengan harga } \\
\text { saat membayar dikasir. }\end{array}$ \\
\hline 9 & Karena pastinya hrg lbh up-to-date. \\
\hline 10 & lebih praktis \\
\hline 11 & mudah mengetahui harga barang \\
\hline 12 & Bisa jelas harganya \\
\hline 13 & $\begin{array}{l}\text { Nyaman, tidak perlu menanyakan harga kepada } \\
\text { petugas dan itu termasuk suatu ide yang cukup } \\
\text { modern berbeda dengan yang lain/yang saya } \\
\text { jumpai di kota blitar ini. }\end{array}$ \\
\hline 14 & Harga valid dan selalu update \\
\hline 15 & $\begin{array}{l}\text { Nyaman karena kita bisa menentukan belanja } \\
\text { yang sesuai budget kita. Tidak nyamannya tiap } \\
\text { memilih barang yang belum tahu harga saat itu } \\
\text { harus ke mesin jadi bisa berkali kali jalan. }\end{array}$ \\
\hline 16 & Nyaman karena harga sudah tersedia \\
\hline 17 & $\begin{array}{l}\text { Mudah dan cepat, karena tidak perlu mencari } \\
\text { pelayan untuk sekedar tanya harga }\end{array}$ \\
\hline 18 & Nyaman krn lebih efisien \\
\hline 19 & $\begin{array}{l}\text { Saya dapat mengetahui harga tanpa menunggu } \\
\text { bertanya pada karyawan }\end{array}$ \\
\hline 20 & $\begin{array}{l}\text { Lebih mudah melihat harga barang tanpa harus } \\
\text { tanya ke pegawai Sea Mart }\end{array}$ \\
\hline 21 & $\begin{array}{l}\text { Tanpa harus bertanya kepada karyawan sudah } \\
\text { bisa mengetahui harga }\end{array}$ \\
\hline 22 & Solutif transparan \\
\hline 23 & Lebih fleksibel \\
\hline 24 & Lebih cepat \\
\hline 25 & $\begin{array}{l}\text { Nyaman, tidak perlu menanyakan harga kepada } \\
\text { petugas dan itu termasuk suatu ide yang cukup } \\
\text { modern berbeda dengan yang lain/yang saya } \\
\text { jumpai di kota blitar ini. }\end{array}$ \\
\hline 26 & Nyaman nyaman aja \\
\hline
\end{tabular}


Tabel 6. Alasan Responden Merasa Tidak Nyaman dengan Penggunaan Mesin Pemindai

\begin{tabular}{|c|c|}
\hline No & Alasan \\
\hline 1 & $\begin{array}{l}\text { Kurang efektif terlalu banyak memakan waktu } \\
\text { untuk mengetahui harga }\end{array}$ \\
\hline 2 & $\begin{array}{l}\text { Ketika ingin melihat harga harus antri terlebih } \\
\text { dahulu apabila swalayan sedang ramai }\end{array}$ \\
\hline 3 & $\begin{array}{l}\text { Harus mencari letak pemindai, ada barcode yang } \\
\text { tidak terbaca oleh pemindai }\end{array}$ \\
\hline 4 & $\begin{array}{l}\text { kadang mesin error tidak mendeteksi barcode, } \\
\text { tidak efektif karena perlu berjalan kaki menuju } \\
\text { mesin pemindai }\end{array}$ \\
\hline 5 & $\begin{array}{l}\text { Bikin proses belanja lama kalo musti cek harga } \\
\text { dulu ke mesin }\end{array}$ \\
\hline 6 & 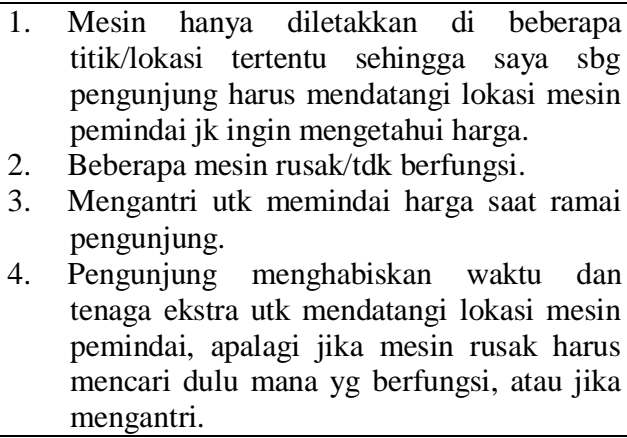 \\
\hline 7 & Banyak yang rusak \\
\hline 8 & $\begin{array}{l}\text { Mesin pemindai tidak semuanya berfungsi. Dan } \\
\text { tidak berfungsi dengan baik }\end{array}$ \\
\hline 9 & Tidak terdeteksi \\
\hline 10 & balik ke mesin \\
\hline 11 & $\begin{array}{l}\text { Lokasinya tidak merata dan kadang mesin tidak } \\
\text { bisa digunakan }\end{array}$ \\
\hline 12 & $\begin{array}{l}\text { Terlalu ribet jika harus cek harga barang satu } \\
\text { persatu }\end{array}$ \\
\hline 13 & $\begin{array}{l}\text { sensor pemindai yang terkadang tidak bisa } \\
\text { membaca barcode }\end{array}$ \\
\hline 14 & harus bolak balik melihat harga dikomputer \\
\hline 15 & $\begin{array}{l}\text { Terlalu lama dan sring kli trobel ktika hrs } \\
\text { memilih hrga yg ekonomis dan byk brg yg } \\
\text { dtinggal menumpuk dimeja pemindai shga trlihat } \\
\text { berantakan }\end{array}$ \\
\hline 16 & $\begin{array}{l}\text { Ribet aja. Seharusnya kan langsung ada harga } \\
\text { tinggal jadi beli atau tidak }\end{array}$ \\
\hline 17 & Repot \\
\hline 18 & Kadang agak lama terdeteksi barcode nya \\
\hline 19 & Harus bolak balik ke mesin pemindai,repot \\
\hline 20 & Harus bolak balik tempat untuk mengecek harga \\
\hline 21 & $\begin{array}{l}\text { Terlalu lama ngecek satu2 karena mesin terbatas } \\
\text { jadi kadang antri.. }\end{array}$ \\
\hline 22 & harus scan harga berkali kali \\
\hline 23 & $\begin{array}{l}\text { Sebagai pelanggan, kita diharapkan } \\
\text { mendapatkan informasi terkait harga produk } \\
\text { secara langsung. Dengan disediakannya label } \\
\text { harga di dekat produk, akan membuat pelanggan } \\
\text { langsung mengetahui harga suatu produk secara } \\
\text { langsung. Ketika hanya diberikan mesih } \\
\text { pemindai, maka pelanggan harus menuju ke } \\
\text { tempat mesin pemindai terdekat, mengecek } \\
\text { harga, bila setuju masukkan ke keranjang, bila } \\
\text { tidak setuju pelanggan harus mengembalikan } \\
\text { barang ke rak. Membutuhkan waktu. Namun, } \\
\text { alangkah baiknya jika kehadiran mesin pemindai } \\
\text { harga tidak menghilangkan label harga yang } \\
\text { tertera di dekat barang. Mesin pemindai, }\end{array}$ \\
\hline
\end{tabular}

\begin{tabular}{|l|l|}
\hline & $\begin{array}{l}\text { disediakan untuk mengantisipasi bila ada label } \\
\text { harga yang hilang atau rusak. }\end{array}$ \\
\hline 24 & Ribet dan terkadang harus antri. \\
\hline 25 & $\begin{array}{l}\text { Karena harus antri dan kadang mesin tidak } \\
\text { menyala }\end{array}$ \\
\hline
\end{tabular}

Tabel 7. Penilaian Responden atas Kehadiran Pemindai Harga Android

\begin{tabular}{|c|l|c|}
\hline No & Pilihan & Jumlah \\
\hline 1 & Lebih baik & 31 \\
\hline 2 & Sama saja & 7 \\
\hline 3 & Lebih buruk & 4 \\
\hline 4 & Lainnya & 8 \\
\hline
\end{tabular}

Dari kuisioner yang telah diberikan kepada responden, meskipun pada awalnya banyak yang merasa nyaman dengan keberadaan mesin pemindai harga yang telah tersedia saat ini, namun Ketika ditawari alternatif lain berupa pemindai harga berbasis android mayoritas memberikan pendapat bahwa dengan adanya aplikasi pemindai harga berbasis android akan menjadikan pengalaman berbelanja mereka menjadi lebih baik sehingga dapat disimpulkan bahwa aplikasi pemindai harga berbasis android memang diperlukan.

\subsection{Halaman Beranda}

Halaman beranda merupakan halaman yang muncul setelah splashscreen pada halaman ini akan ditampilkan riwayat toko yang telah dikunjungi oleh pengguna. Daftar riwayat pada halaman ini diurutkan berdasarkan waktu kunjungan secara descending sehingga toko yang terakhir dikunjungi akan muncul di awal daftar.

Setiap pengguna memilih riwayat akan dicatat pada sistem sebagai kunjungan toko yang bisa digunakan sebagai sumber data analisa pengunjung. Jika pengguna tidak ingin menggunakan daftar toko yang ada pada riwayat, maka pengguna bisa menekan tombol "Scan".

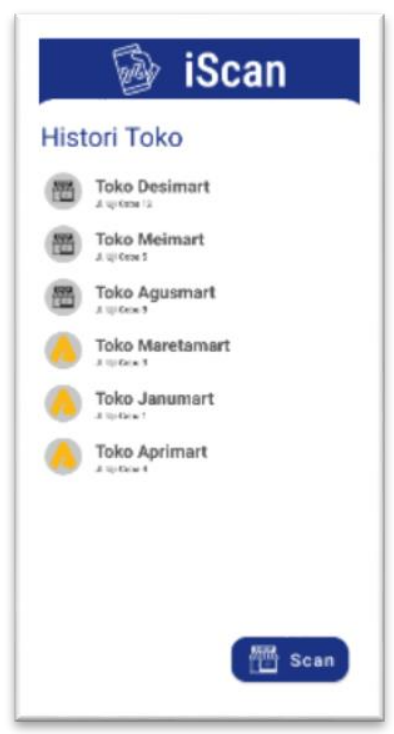

Gambar 5. Halaman Beranda 


\subsection{Halaman Pemindai Toko}

Halaman ini akan menampilkan sebuah pemindai untuk memindai barcode toko yang kemudian datanya akan digunakan untuk menentukan toko mana yang datanya akan diambil. Setelah pengguna memindai barcode, maka data yang terbaca akan dikirimkan ke server. Setiap pengguna melakukan pemindaian maka akan dicatat pada sistem sebagai kunjungan toko yang bisa digunakan sebagai sumber data analisa pengunjung.

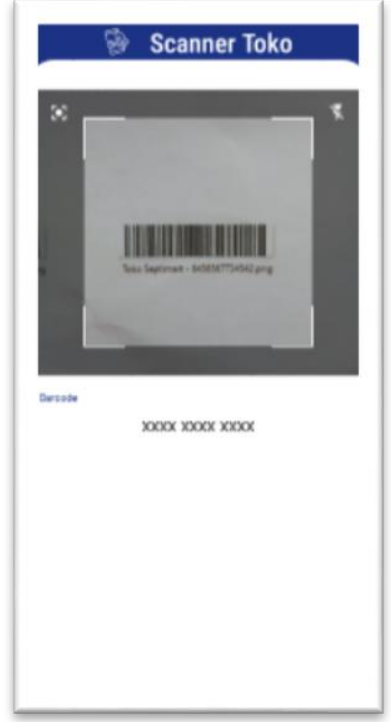

Gambar 6. Halaman Pemindai Toko

\subsection{Halaman Pemindai Produk}

Halaman ini akan menampilkan sebuah pemindai untuk memindai barcode produk. Setelah pengguna memindai barcode, maka data yang terbaca akan dikirimkan ke server. Setiap pengguna melakukan pemindaian maka akan dicatat pada sistem yang nantinya bisa digunakan sebagai sumber data analisa produk.

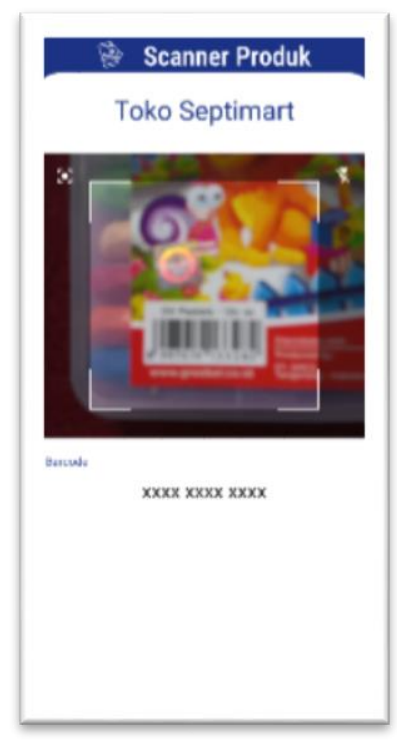

Gambar 7. Halaman Pemindai Produk

\subsection{Halaman Detail Produk}

Halaman ini digunakan untuk menampilkan detail produk yang diterima dari server diantaranya: nama produk, gambar, harga, barcode, dan deskripsi. Jika pengguna ingin melakukan pemindaian ulang maka bisa dilakukan dengan memilih tombol "rescan" sedangkan jika ingin kembali ke beranda langsung maka bisa memilih tombol "exit". Selain itu juga ditampilkan rekomendasi produk-produk sejenis untuk menarik pembeli berbelanja lebih banyak.

Pada halaman inilah metode TOPSIS diterapkan untuk memberikan daftar rekomendasi produk kepada konsumen. Daftar rekomendasi yang diberikan kepada konsumen tersusun berdasarkan ranking produk yang dinilai berdasarkan beberapa faktor berikut:
a. Rating produk
b. Jumlah produk dipindai
c. Harga
d. Rating toko
e. Jumlah terjual

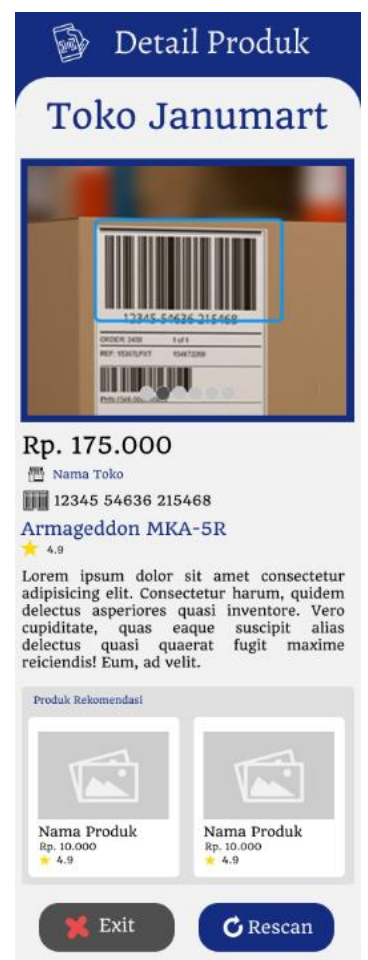

Gambar 8. Halaman Detail Produk

Setelah melalui proses perangkingan maka selanjutnya daftar rekomendasi ditampilkan kepada pengguna dengan urutan menampilkan produk terbaik terlebih.

\subsection{Pengujian Black Box}

Pengujian diperlukan untuk menvalidasi apakah sistem yang dirancang telah sesuai dengan yang diharapkan. Pada penelitian ini peneliti melakukan pengujian dengan metode black box. Pengujian 
dilakukan dengan menggunakan beberapa perangkat android Realme U1 yang menggunakan android versi 9.

Pada pengujian ini tingkat keberhasilan pengujian dihitung menggunakan rumus sebagai berikut:

$$
\text { Result } \quad=\frac{\text { Valid }}{\text { Total }} \times 100 \%
$$

Keterangan:

$$
\begin{array}{ll}
\text { Result } & =\text { Persentase keberhasilan pengujian } \\
\text { Valid } & =\text { Jumlah pengujian valid }
\end{array}
$$

Tabel 8. Hasil pengujian black box

\begin{tabular}{|c|l|c|c|}
\hline No & \multicolumn{1}{|c|}{ Halaman } & $\begin{array}{c}\text { Total } \\
\text { Skenario }\end{array}$ & $\begin{array}{c}\text { Sesuai } \\
\text { Harapan }\end{array}$ \\
\hline 1 & Beranda & 5 & 5 \\
\hline 2 & Pemindai Toko & 5 & 4 \\
\hline 3 & Pemindai Produk & 5 & 4 \\
\hline 4 & Detail Produk & 3 & 3 \\
\hline
\end{tabular}

Dari 18 skenario pengujian yang diujikan pada perangkat android Realme U1 menunjukan hasil 16 skenario berhasil dan 2 skenario gagal sehingga bisa disimpulkan aplikasi ini berjalan $88,89 \%$ sesuai dengan yang diharapkan.

\section{KESIMPULAN}

Berdasarkan penelitian yang telah dilakukan dapat disimpulkan beberapa hal sebagai berikut:

1. Perancangan aplikasi pemindai harga barang berbasis android dilakukan dengan beberapa tahap yakni: membuat flowchart sistem, membuat DFD dan ERD, membuat rancangan antarmuka pengguna, pembuatan aplikasi android dan juga pembuatan aplikasi server. Pengimplementasian aplikasi pemindai harga barang berbasis android ini dibuat tanpa sistem login dengan tujuan meningkatkan efisiensi dan kemudahan penggunaan aplikasi. Untuk menggunakan aplikasi ini pengguna terlebih dahulu harus memindai barcode toko untuk menentukan lokasi pengguna kemudian setelah itu pengguna bisa memindai barcode produk yang mana setiap barcode terbaca oleh aplikasi maka akan dicari di server dan setelah data produk tersebut ditemukan akan langsung ditampilkan kepada pengguna.
2. Pengujian aplikasi pemindai harga barang berbasis android ini dilakukan menggunakan perangkat android Realme U1 yang menggunakan android versi 9 / pie menggunakan metode black-box dan mendapatkan hasil 88,89\% sesuai dengan harapan. Hasil pengujian mendapatkan nilai tersebut dipengaruhi oleh berbagai faktor seperti: kompatibilitas pustaka pemindai dengan perangkat pengguna, versi android pengguna, dan juga perangkat keras pengguna.

\section{DAFTAR PUSTAKA}

[1] Ardana, S. B., Taufik, M., Studi, P., Telekomunikasi, J., Elektro, T., \& Malang, P. N. (2019). Rancang bangun sistem pembelian menggunakan pemindaian qr code di inception 99 stArdana, S. B., Taufik, M., Studi, P., Telekomunikasi, J., Elektro, T., \& Malang, P. N. (2019). Rancang bangun sistem pembelian menggunakan pemindaian qr code di inception 99.

[2] Febiyanti, C. A. (2018). Implementasi Barcode Scanner Pada Aplikasi Cek Harga Dan Hitung ( Si-Ceking ) Berbasis Mobile. Jurnal Teknologi Dan Sistem Komputer, 6(2), 26-33.

[3] Hwang, Ching-Lai dan Kwangsun Yoon. (1981). Multiple Attribute Decision Making, Methods and Application. Berlin:SpringerVerlag

[4] Ohy, J. (2010). Masih Relevankah Strategi Marketing Mix Meningkatkan Kepuasan Pelanggan. JDM - Jurnal Dinamika Manajemen, $\quad$ 1(2), 162-168. https://doi.org/10.15294/jdm.v1i2.2473

[5] Putra Yudha, I. P. A., Sudarma, M., \& Arya Mertasana, P. (2018). Perancangan Aplikasi Sistem Inventory Barang Menggunakan Barcode Scanner Berbasis Android. Jurnal SPEKTRUM, 4(2), 72. https://doi.org/10.24843/spektrum.2017.v04.i 02.p10

[6] Suryawan, M. A., Hasiri, E. M., \& Ode, K. (2020). Penerapan Sistem QR Code dan Barcode dalam Menghitung Belanja di Swalayan Berbasis Android. Informatika, 9(2), $1-9$. 